Игнатова Наталья Петровна

воспитатель

ГКУ СО КК «Ейский СРЦН»

г. Ейск, Краснодарский край

DOI: $10.21661 / r-497587$

\title{
ИНКЛЮЗИВНАЯ ОБРАЗОВАТЕЛЬНАЯ СРЕДА \\ КАК УСЛОВИЕ РАЗВИТИЯ И СОЦИАЛЬНОЙ АДАПТАЦИИ ДЕТЕЙ С ОСОБЫМИ ОБРАЗОВАТЕЛЬНЫМИ ПОТРЕБНОСТЯМИ
}

Аннотация: в данной статье отражён положительный опыт деятельности соииильно- реабилитационного центра по развитию и адаптации детей со сложными дефектами развития. Существующие проблемы изложены последовательно. Акиентированное внимание уделяется понятиям «инклюзивное образование» «сочиальные пробы», как вариантам адаптащии воспитанников с ограниченными возможностями здоровья. Материал статьи даст возможность педагогам осмыслить проблемы организачии инклюзивного образования и возможные пути их решения, а также нащелен на педагогических работников сочиально-реабилитационных цеентров, педагогов общего и дополнительного образования, студентов педагогических учебных заведений.

Ключевые слова: структура инклюзивной образовательной среды, ограниченные возможности здоровья (OB3), образовательная среда, образовательная программа, комплексное сопровождение, сочиально-психологическая адаптацุия.

Инклюзивная образовательная среда - это совокупность составляющей образовательной среды - предметно-пространственная развивающая образовательная среда; характер взаимодействия с окружающими; отношение ребенка к окружающему миру; адаптация к особым образовательным потребностям воспитанников с ограниченными возможностями здоровья.

В современной окружающей среде увеличивается численность детей с ограниченными возможностями здоровья (OB3), испытывающих затруднения 
в освоении образовательной программы. Для таких воспитанников требуется создание соответствующих условий обучения и воспитания, возникает необходимость комплексного сопровождения таких детей в условиях образовательных учреждений. Другими словами, необходима доступная образовательная среда, позволяющая детям с ОВ3 реализовать в полном объёме личные образовательные потребности. Поэтому возникает необходимость создания инклюзивного образовательного пространства для детей с ОВЗ, предполагающего решение проблемы образования детей с ОВ3 за счет адаптации образовательного пространства к нуждам каждого ребенка, включая образовательный процесс, методическую гибкость и вариативность, благоприятный психологический климат, приспособление учебных помещений обеспечивающих участие детей в образовательном процессе в полном объёме.

Здесь уместно уточнить определение понятий «Образовательная среда» и «Инклюзивная образовательная среда» - это система влияний и условий формирования личности; совокупность возможностей для ее развития, понимание образования как сферы социальной жизни, а среды как фактора образования. обеспечение для субъектов образовательного процесса возможности эффективного саморазвития. Необходимо создать инклюзивную образовательную среду (ИОС) для качественного образования детей с ограниченными возможностями здоровья.

Цель статьи - выявление особенностей образовательной деятельности в условиях инклюзивной образовательной среды. Для реализации поставленной цели необходимо разрешение таких проблем как создание инклюзивной образовательной среды, определение эффективных форм социально-реабилитационной адаптации и развития детей с ОВ3, формирование инклюзивной компетентности педагогов, воспитателей, воспитанников, родителей, вовлечение их в образовательный процесс социально-реабилитационного центра. В основе взяты работы и исследования отечественных и зарубежных ученых: М.M. Семаго, Н.Я. Семаго, Е.В. Носовой, С.Д. Забрамной, О.В. Боровик, Н.Н. Малофеева, Н.Д. Шматко и др. Инклюзивная образовательная среда базируется 
на принципах дошкольного и инклюзивного образования, осуществляемого в рамках реализации Основной образовательной программы ДО и рабочей программы педагога, адаптированной к детям с особыми образовательными потребностями. Такая деятельность выстраивается планово, системно, поэтапно в двух направлениях. Решение задач в таком ракурсе определяют формы работы и гарантируют результат.

Обеспечить социально-психологическую адаптацию детей с ОВ3 к образовательной среде группы поможет игровая и практическая совместная деятельность. Это могут быть игры взаимообучения: «Покажи, научи, расскажи», «Монополия», «Аукцион доброты», «Поучительные сказки», «Занимательные мультфильмы» и др. Сформированность инклюзивной компетентности педагогов. родителей помогут педагогические игры: «Лучшие друзья», «Консилиум педагогических знаний», «Аукцион идей» и др.

Создание благоприятных условий развития детей по формированию ЗОЖ и основ правильного питания в соответствии с их возрастными и индивидуальными особенностями развития помогут проектная деятельность, конкурсы, концерты, социальные акции, праздники, тематические и творческие гостиные и пр.

Результатом создания инклюзивной образовательной среды будет значительное снижение уровня тревожности; облегчение процесса адаптации детей с OB3 к образовательным программам, признание каждого ребенка полноценным участником (субъектом) образовательных отношений- это и будет основным условием развития и социальной адаптации детей с особыми образовательными потребностями.

Только данная образовательная деятельность полностью не снимает проблему изоляции детей с особыми образовательными потребностями. Отсутствие возможности приобретения реального социального опыта взаимодействия с социумом значительно затрудняет адаптацию ребенка к начальной школе и делает проблемным дальнейшее общение со сверстниками, взрослыми, окружением и подтверждает потребность в использовании других методов. 
Например, социальные практики. С учетом мнения Г.М. Беспаловой и Н.М. Виноградовой, Е.В. Бондаревской, Н.Б. Крыловой, А.В. Запесоцкого, «социальные практики» это ситуативное, самостоятельное приобретение, повторение разного опыта общения и взаимодействия в различных группах, командах, сообществах и общественных структурах со взрослыми и сверстниками. Это освоение положительного жизненного опыта, сопереживания, средство получения и осваивания информации о социальных объектах, явлениях, получение и осознание своего опыта социального взаимодействия. Это универсальная форма организации социальной практики: выезд в другие образовательные учреждения, в рамках работы агитбригады, где воспитанники делились опытом удачных проектов и выступали с театрализованными представлениями (рис. 11); посещение учреждений дополнительного образования в качестве участников мероприятий и соревнований; общение на мастер-классах с детьми по одной тематике; мероприятия на природе, на объектах социального и развлекательного назначения, участие во всевозможных и доступных социальных акциях, флэш-мобах вместе со здоровыми сверстниками и др. В результате социальных практик воспитанники получают представления о социальном окружении, способах взаимодействия и общения, об уровне своих практических возможностей; приобретают новый опыт социального взаимодействия. Результативность мониторинга по адаптации детей (опрос родителей, законных представителей) показывает стабильную прогрессирующую динамику - 100\% адаптация к новым социальным условиям. Приобретенный опыт взаимодействия и сотрудничества позволяет сохранить активную позицию полноправного участника образовательных отношений и в общеобразовательных, музыкальных, спортивных школах, учреждениях дополнительного образования и пр. В результате, деятельность педагога, воспитателя в условиях инклюзивной образовательной среды способствует успешному освоению общеобразовательной программы любого уровня образования, разностороннему развитию воспитанников с учетом особых условий адаптации. То есть инклюзивная образовательная среда это и есть необходимое условие развития и социальной адаптации детей с особыми образовательными потребностями. 


\section{Список литературы}

1. Ариарский МА. Прикладная культурология как область научного знания и социальной практики. - СПб., 1999.

2. Арнаутова Е.П. Социально-педагогическая практика взаимодействия семьи и детского сада в современных условиях [Электронный ресурс]. - Режим доступа: detsad-journal.narod.ru/20044/ Arnautova.rtf.

3. Баимбетов АА. Молодежь в кризисном социуме / А.А. Баимбетов, Р.Т. Насибуллин, Г.А. Кабакович, Ф.Г. Хайруллин / под ред. Р.Т. Насибуллина. M., 1998.

4. Агавелян М.Г. Взаимодействие педагогов ДОУ с родителями / М.Г. Агавелян, Е.Ю. Данилова, О.Г. Чечулина. - М.: ТЦ «Сфера», 2009. - 128 с.

5. Гудина Т.В. Педагогические ресурсы социокультурной реабилитации детей-инвалидов. - Вологда, 2009.

6. Гудина Т.В. Организационные условия социокультурной реабилитации инвалидов. // Вестник Костромского государственного университета им. Н.А. Некрасова. - 2009. - Т. 15, №3. - С. 331-335.

7. Гудина Т.В. Психолого-педагогические условия обеспечения равных возможностей детей-инвалидов // Динамика научных исследований: материалы VIII Международной научно-практической конференции. - 2012.

8. Давыдова О.И. Компетентностный подход в работе дошкольного образовательного учреждения с родителями: учебное пособие / О.И. Давыдова, А.А. Майер. - СПб.: Детство-Пресс, 2012. - 128 с.

9. Денисова ОА. Комплексное многоуровневое психолого-педагогическое пространство для социально-культурной интеграции лиц с сенсорными нарушениями. - Череповец, 2006.

10. Денисова ОА. Характеристика социокультурной адаптации и интеграции лиц с сенсорными нарушениями / О.А. Денисова, И.А. Бучилова, В.Н. Поникарова // Социально-гуманитарные знания. - 2007. - №7. - С. 151-158.

11. Забрамная С.Д. От диагностики к развитию / С.Д. Забрамная, О.В. Боровик. - М: В. Секачёв, 2015. 
12. Зрелова Т.А. Культурно-досуговая деятельность как средство социальной интеграции детей-инвалидов: автореф. дис. канд. пед. наук / Т.А. Зрелова. СПб., 2000.

13. Крылова Н. Каким должно быть общение детского сада с семьей? // Воспитание дошкольников. - 2009. - №3. - С. 14-27.

14. Монастырская Л.В. Социокультурный потенциал семьи как средство позитивной социализации ребенка // Вторые Державинские чтения. - Тамбов, 1996. - C. 28.

15. Никитина Г.В. Социальная практика как педагогическое понятие. Чита: Молодой ученый, 2011.

16. Об утверждении федерального государственного образовательного стандарта дошкольного образования: приказ Министерства образования и науки Российской Федерации (Минобрнауки России) от 17 октября 2013 г. №1155.

17. Крылова Н.Б. Свободное воспитание в семье и школе: культурные практики детей / Н.Б. Крылова. - М.: Сентябрь, 2007. - 192 с.

18. Семаго Н.Я. Проблемные дети: основы диагностической и коррекционной работы психолога / Н.Я. Семаго, М.М. Семаго - М.: АРКТИ, 2000. - 207 с.

19. Об образовании в Российской Федерации: Федеральный закон от 29.12.2012 г. №273-Ф3.

20. Чащина АА. Социальное проектирование и социальная практика // Вестник Красноярского государственного университета. Гуманитарные науки.Красноярск, 2006. - №3/2. - С. 43-46. 